\title{
Analisis Corporate Social Responsibility Dalam Aspek Perpajakan Dan Pengaruhnya Terhadap Penghindaran Pajak
}

\author{
Agus Bandiyono dan Gerardo Budi Satya Dewangga \\ Politeknik Keuangan Negara STAN \\ Email: \\ agusbandiyono@pknstan.ac.id; ardoimut@gmail.com
}

\begin{abstract}
The obligations to implement CSR in Indonesia is regulated in the Limited Liability Company Law. The disclosure of CSR implementation can be stated by the company in a sustainability report. The tax regulations in Indonesia do not directly regulate the term CSR. In addition, the implementation of CSR can be used as a means of tax avoidance by companies because there are costs for implementing CSR that are deductible. Therefore, this study was conducted to analyze the concept of CSR in the Indonesian taxation aspect, conduct a descriptive analysis of CSR disclosure in the sustainability report, and determine the effect of CSR disclosure on tax avoidance actions in the major financial company listed on IDX. The first result of this research is that the CSR obligation holders according to the Company Law are also the Subjects of Corporate Tax in the Income Tax Law. Costs related to the implementation of CSR have not been regulated directly in the Income Tax Law. However, there are some costs that are consistent with the CSR disclosure standards in GRI G4. Second, the average CSR disclosure by major financial service companies on the IDX is only $27.2 \%$. Third, this study shows that CSR disclosure has no effect on tax avoidance.
\end{abstract}

Keywords: CSR, taxation, CSR disclosure, tax avoidance.

Abstrak: Kewajiban pelaksanaan CSR untuk negara Republik Indonesia dijelaskan di Undang-Undang Perseroan Terbatas. Pengungkapan pelaksanaan CSR dapat dinyatakan oleh perusahaan dalam sebuah sustainability report. Peraturan perpajakan di Indonesia belum mengatur secara langsung istilah CSR. Pelaksanaan CSR juga dapat menyebabkan terjadinya penghindaran pajak oleh perusahaan karena adanya biaya-biaya pelaksanaan CSR yang bersifat deductible. Terkait hal tersebut, riset ini ditujukan untuk menganalisis pengungkapan CSR dalam perpajakan Indonesia, melakukan analisis deskriptif atas pengungkapan CSR dalam sustainability report, dan mengetahui pengaruh CSR terhadap terjadinya penghindaran pajak untuk perusahaan jasa keuangan utama pada Bursa Efek Indonesia. Hasil riset ini adalah bahwa pemangku kewajiban CSR menurut UUPT juga merupakan Subjek Pajak Badan dalam UU PPh. Biaya-biaya pelaksanaan CSR belum diatur secara langsung dalam UU PPh. Terdapat beberapa biaya yang selaras dengan standar pengungkapan CSR dalam GRI G4. Kedua, rata-rata pengungkapan CSR oleh perusahaan-perusahaan jasa keuangan di BEI hanya sebesar 27,2\%. Ketiga, riset ini mengungkapkan bahwa penyajian CSR tidak berpengaruh pada terjadinya penghindaran pajak.

Kata Kunci : CSR, perpajakan, pengungkapan CSR, penghindaran pajak. 


\section{PENDAHULUAN}

Corporate Social Responsibility (CSR) atau disebut sebagai tanjung jawab social perusahaan didefinisikan sebagai klaim para pemegang kepentingan atau stakeholders, supaya perusahaan tersebut tidak selalu bekerja demi memenuhi kebutuhan para pemegang saham atau sering disebut shareholders, namun juga demi kepentingan pihak pemegang kepentingan dalam implementasi usaha, seperti para komunitas lokal, pekerja, konsumen, lingkungan, pemerintah, dan Lembaga Swadaya Masyarakat (Indrawan dan Siti, 2011; Angrayani, 2016; Awaliyah dan Vestari, 2018; Azra, 2012). Proses produksi dan manajemen informasi yang berkaitan dengan etika dan bentuk tanggung jawab sosial dilihat sebagai bagian kecil dari kontrak sosial antara pihak perusahaan dan masyarakat. Kegagalan dalam memenuhi kewajiban tanggung jawab berpotensi merusak kredibilitas organisasi (Whait et al., 2018).

Pemerintah Indonesia telah mengatur kebijakan mengenai pertanggungjawaban sosial perusahaan melalui Undang Undang No 40 tahun 2007 mengenai Perseroan Terbatas (UUPT). Dalam Pasal 74 ayat (1) UUPT, dinyatakan bahwa perseroan yang melakukan suatu aktivitas usaha di bagian dan atau berhubungan dengan sumber daya alam harus melakukan tanggung jawab sosial perusahaan. Terkait hal tersebut, pelaksanaan Corporate Social Responsibility di Indonesia bukan hanya sekedar wacana saja, melainkan sebuah tindakan yang sudah memiliki payung hukum dan harus dikerjakan oleh perusahaan. Pengungkapan tanggung jawab social atau Corporate Social Responsibility yang dilakukan oleh perusahaan dapat disusun dalam sebuah sustainability report. (Harahap, 2010). Salah satu standar untuk menyusun sebuah sustainability report adalah Global Reporting Initiative (GRI) Sustainability Reporting Guidelines. Pedoman atau standar ini dibuat agar suatu organisasi atau perusahaan dapat mengungkapkan dampak yang paling penting dari Corporate Social Responsibility, baik negatif atau positif, pada masyarakat, ekonomi dan lingkungan (Wulolo dan Rahmawati, 2017; Kolk, 1989).

Bagi suatu negara, khususnya di Indonesia, Pajak memiliki peranan penting untuk menyokong perekonomian di Indonesia (Sudaryo dan Yudanegara, 2017). Hal tersebut dikarenakan sumber penerimaan utama negara berasal dari pajak, berdasarkan data dari Badan Pusat Statistik (2017). Berdasarkan data dari APBN tahun 2018, sebesar 85\% penerimaan negara berasal dari pajak, baik Pajak Penghasilan, Pajak Pertambahan Nilai, atau Pajak Bumi dan Bangunan dan jenis-jenis pungutan pajak lain. Pada umumnya, menurut UU No. 36 tahun 2008 mengenai Pajak Penghasilan, suatu perusahaan diklasifikasikan sebagai bentuk badan dalam peraturan perundang-undangan perpajakan, sehingga perusahaan akan dikenakan Pajak penghasilan Badan ( $\mathrm{PPh}$ Badan). Penghitungan pajak penghasilan akan dilakukan terhadap laba bersih perusahaan, yaitu peredaran bruto dikurangi dengan biaya atau beban yang telah dirilis oleh Perusahaan masing-masing.

UU No 36 tahun 2008 mengenai Pajak Penghasilan mengatur perlakuan atas berbagai biaya yang dikeluarkan oleh perusahaan. Adanya peraturan atas biaya-biaya tersebut dapat mengakibatkan terjadinya koreksi fiskal baik positif maupun negatif yang berdampak pada laba bersih perusahaan yang semakin besar atau kecil untuk dikenakan pajak. Namun, pada peraturan tersebut, perlakuan atas biaya Corporate Social Responsibility belum dinyatakan dengan jelas. Hanya terdapat beberapa jenis objek 
Corporate Social Responsibility saja yang termuat dalam Undang-Undang Pajak Penghasilan.

Bagi pihak perusahaan, pembayaran pajak adalah siklus perpindahan harta dari perusahaan untuk negara sehingga pajak adalah cost yang lumayan besar bagi perusahaan (Femitasari, 2014). Hal tersebut akan mengakibatkan perusahaan memiliki kecondongan melaksanakan tindakan penghindaran pajak (tax avoidance). Penelitian yang mencari kaitan dari CSR dengan penghindaran pajak membuahkan hasil riset yang beraneka ragam. Berdasarkan penelitian (Lanis dan Richardson, 2012), perusahaan dengan tingkat tanggung jawab sosial yang besar mempunyai tingkat penghindaran pajak yang kecil. Di sisi lain, riset yang disusun oleh (Femitasari, 2014), CSR memiliki pengaruh signifikan positif atas penghindaran pajak.

Berdasarkan uraian di atas, penulis ingin melakukan analisis mengenai konsep biaya CSR dalam aspek peraturan perpajakan di negara kita, melakukan analisis deskriptif penyampaian CSR dalam sustainability report yang disusun oleh perusahaan jasa keuangan utama yang tercantum dalam Bursa Efek Indonesia (BEI), dan melakukan uji pengaruh penyajian CSR terhadap tindakan penghindaran pajak yang dilakukan oleh jasa keuangan utama yang terdapat di BEI.

Rumusan Masalah. Bagaimana konsep biaya CSR dalam aspek peraturan perpajakan di Indonesia? ; Bagaimana analisis deskriptif penyajian CSR yang disusun oleh perusahaan jasa keuangan utama yang tercantum di BEI dalam sustainability report berdasarkan GRI Sustainability Report Guidelines? Apakah penyajian CSR memiliki pengaruh atas tindakan penghindaran pajak yang dilakukan oleh perusahaan jasa keuangan yang terdapat di BEI?

Tujuan Penelitian. Menganalisis konsep biaya CSR pada aspek peraturan perpajakan pada negara kita; Melakukan analisis deskriptif penyajian CSR yang disusun oleh perusahaan jasa keuangan utama yang muncul di BEI dalam sustainability report berdasarkan GRI Sustainability Report Guidelines; Mengetahui pengaruh biaya CSR atas tindakan penghindaran pajak perusahaan jasa keuangan utama yang tercantum di BEI.

\section{Kajian Pustaka dan pengembangan hipotesis}

Peraturan Perundang-undangan Perpajakan Mengenai Biaya. Mekanisme penghitungan penghasilan kena pajak untuk wajib pajak dalam negeri maupun Bentuk Usaha Tetap (BUT) dilakukan dengan mengurangkan penghasial bruto dengan berbagai biaya. Biaya tersebut merupakan biaya yang digunakan untuk meminta, memperoleh, dan menyimpan penghasilan. Atas bermacam-macam biaya yang diijinkan untuk dikurangi dari penghasilan bruto untuk menghitung Penghasilan Kena Pajak terdapat pada pasal 6 UU No 36 tahun 2008 mengenai PPh. Terdapat 13 jenis biaya yang dapat dibiayakan untuk mengurangi pendapatan kotor. Sedangkan berbagai biaya yang tidak boleh dikurangkan untuk mengambil pendapatan kotor diatur pada pasal 9.

Definisi CSR. Sampai sekarang, belum terdapat kesepakatan resmi yang sama dari para ahli mengenai definisi dari Corporate Social Responsibility, meski esensi dari pendapatpendapat tersebut sudah hampir sama. Berikut ini adalah beberapa definisi dari Corporate Social Responsibility. 
(Weber dan Wasieleski, 2018) menyatakan bahwa CSR yaitu kegiatan yang dilaksanakan oleh perusahaan dengan sadar serta sengaja untuk meningkatkan kesejahteraan sosial bagi mereka yang terdampak oleh kegiatan ekonomi perusahaan, dalam bukunya yang berjudul Corporate Social Responsibility: Bussiness \& Society 360. Corporate Social Responsibility diartikan oleh (Hopkins, 2003) sebagai tindakan memperlakukan para pemilik kepentingan organisasi dengan etis dan bertanggung jawab. Para pemilik kepentingan yang dimaksud dalam pernyataan tersebut berasal dari dalam maupun luar perusahaan - lingkungan di sekitar perusahaan tersebut berada. Dari pendapat para ahli dimaksud, CSR disimpulkan sebagai kegiatan yang dilaksanakan oleh organisasi untuk mensejahterakan para pemangku kepentingan secara sadar dan didasarkan pada etika dan tanggung jawab.

Sustainability Report. Sustainability report memuat info selain keuangan yang berisi atas info kegiatan lingkungan dan social yang memberi peluang organisasi dapat berkembang secara berkelanjutan. (Yoehana, 2013). Sustainibility report adalah sarana untuk melunasi kewajiban organisasi yang menyampaikan kinerjanya dalam tiga unsur, diantaranya adalah aspek social, aspek lingkungan dan aspek ekonomi. (Khafid dan Mulyaningsih, 2018). Selain itu, sustainability report adalah praktik pengukuran, pengungkapan, serta usaha akuntabilitas dari sustainability activities yang memiliki tujuan demi tercapainya pembangunan berkelanjutan (sustainability development) (Mualiffin, 2016). Berdasarkan konsep tersebut, dapat disimpukan bahwa sustainability report adalah sarana berupa laporan pengungkapan kegiatan pertanggungjawaban lingkungan dan social atau CSR yang dibuat perusahaan demi pembangunan yang berkelanjutan.

Terdapat standar atau pedoman internasional dalam menyusun sustainability report. (Widianto, 2011). Standar pelaporan berkelanjutan tersebut adalah Global Reporting Initiatives (GRI) G4 sustainability report guidelines, yang terdiri dari 3 buku, yaitu Reporting Principles, Standard Disclosure, dan Implementation Manual. (Mahendra, 2015). Standar tersebut memuat indikator-indikator penyajian CSR yang diklasifikasikan dalam tiga unsur, yaitu kategori lingkungan, social dan ekonomi (Wibowo dan Faradiza, 2014). Total jumlah poin indikator penyajian CSR menurut GRI G4 dalam sustainability report berjumlah 91 indikator.

Penghindaran Pajak. Pajak merupakan pendapatan negara yang utama dan harus dipenuhi oleh Wajib Pajak. Namun untuk wajib pajak, pajak merupakan beban yang bisa menurunkan laba. Untuk mengatasi masalah tersebut, wajib pajak bisa melaksanakan tindakan penghindaran pajak (Abdullah, 2020). Penghindaran pajak atau tax avoidance yaitu metode untuk menghindari penyampaian pajak secara resmi yang dilaksanakan oleh wajib pajak memakai metode menurunkan pajak terutang dengan tidak melanggar ketentuan perundang-undangan pajak yang berlaku, atau melalui kata lain melihat kelemahan dari ketentuan pajak (Hutagaol, dkk, 2007). Penghindaran pajak dilaksanakan dengan tanpa melawan hukum yang sah, tetapi penghindaran pajak hanya menggunakan kekurangan atau celah dari ketentuan yang sah. Oleh karena itu, Wajib Pajak yang melakukan tax avoidance Pajak tidak dapat dikatakan melanggar hukum.

Komisi bidang fiskal pada Organization for Economic Cooperation and Development (OECD) dalam (Hidayah, 2017) menjelaskan tiga macam penghindaran pajak: terdapat unsur artifisial bahwa bermacam-macam ketentuan seperti terdapat di 
dalamnya padahal tidak, dan itu dilaksanakan karena tidak adanya faktor pajak; menggunakan loopholes dari UU atau melakukan berbagai ketentuan, namun tidak itu yang seharusnya diartikan oleh penyusun UU; dan pihak konsultan menunjukkan cara atau metode untuk menjalani penghindaran pajak dengan ketentuan bahwa wajib pajak harus menjaga sebaik mungkin.

Teori Legitimasi Positif Dalam Hubungan antara Corporate Social Responsibility dengan Penghindaran Pajak. Apabila ditinjau dari sudut pandang pajak penghasilan, pelaksanaan dan pengungkapan Corporate Social Responsibility bisa dijadikan sarana untuk melakukan penghindaran pajak. Hal tersebut dikarenakan biaya-biaya dan bebanbeban perusahaan dalam melakukan Corporate Social Responsibility dapat dibiayakan untuk mengurangi pendapatan kotor organisasi, sehingga akan diperoleh penghasilan kena pajak yang lebih rendah (Dewi dan Noviari, 2017). Namun, apabila ditinjau dari teori legitimasi, organisasi yang mempunyai rating CSR yang besar memiliki kecenderungan tidak melakukan penghindaran pajak. Teori legitimasi mengungkapkan terkait organisasi mempunyai ikatan dengan masyarakat agar melaksanakan agendanya beralaskan beberapa nilai keadilan serta cara organisasi merespon beberapa komunitas keperluan untuk melegalkan kegiatan organisasi (Hidayah, 2017). Pengungkapan CSR pada dasarnya bertujuan untuk mendapatkan legitimasi positif dari masyarakat (Sayekti dan Wondabio, 2007). Organisasi yang sudah menyampaikan berbagai info tentang CSR sebagai upaya mendapatkan nama yang positif dimaksud berupaya untuk menjaganya. Satu diantara usahanya adalah menurunkan ataupun tidak melaksanakan penghindaran pajak yang bisa menghancurkan nama yang telah positif lewat kegiatan CSR (Hidayah, 2017).

Berdasarkan teori legitimasi tersebut, penulis memiliki hipotesis penelitian bahwa pengungkapan CSR dalam sustainability report yang disusun oleh perusahaan jasa keuangan utama yang terdaftar di BEI berimplikasi negatif kepada penghindaran pajak yang dilaksanakan oleh perusahaan tersebut. Hipotesis tersebut akan diuji dengan indeks pengungkapan CSR sebagai variable bebas dan Effective Tax Rate (ETR) sebagai variable terikat. Semakin tinggi indeks pengungkapan CSR, berimplikasi bahwa perusahaan itu semakin banyak melaksanakan pengungkapan CSR. Semakin tinggi ETR perusahaan, maka perusahaan itu semakin minim melaksanakan tindakan penghindaran pajak. Terkait hal itu, hipotesa statistik yang akan digunakan adalah indeks pengungkapan CSR berpengaruh positif terhadap ETR perusahaan.

\section{METODE}

Metode Pengumpulan Data. Metode pengumpulan data yang dilakukan dalam penelitian ini yaitu metode penelitian kepustakaan dan metode penelitian lapangan. Dalam metode kepustakaan, penulis mengumpulkan data dan informasi melalui literasi yang terkait seperti buku, jurnal, peraturan perundang-undangan, artikel, serta laporan keuangan dan sustainability report perusahaan-perusahaan jasa keuangan utama yang tercantum dalam Bursa Efek Indonesia (Sugiyono, 2013). Sedangkan dalam metode lapangan, penulis melakukan pengumpulan data dengan teknik interview. Interview adalah salah satu teknik pengumpulan data yang dilaksanakan dengan bertatap muka langsung dengan informan namun bisa juga diberikan daftar pertanyaan terlebih dahulu untuk direspon pada lain waktu (Noor, 2011). Penulis akan melakukan wawancara pada salah satu Account 
Representative di Kantor Pelayanan Pajak Madya Semarang untuk memperoleh data dan informasi yang bisa dipakai dalam menganalisa biaya Corporate Social Responsibility dalam aspek perpajakan.

Kerangka Berpikir dan Model penelitian. Corporate Social Responsibility didefinisikan sebagai klaim para pemegang kepentingan atau stackholders supaya perusahaan bukan hanya bertindak demi keperluan para pemegang saham atau shareholders, namun juga demi kepentingan pemegang kepentingan dalam praktek usaha, seperti para pegawai, kelompok internal, Lembaga Swadaya Masyarakat, lingkungan, konsumen dan Pemerintah. (Indrawan dan Siti, 2011). Pelaksanaan CSR telah menjadi suatu kewajiban hokum bagi para pelaku usaha, khususnya perseroan, sejak munculnya UU No. 40 tahun 2007 mengenai Perseroan Terbatas. Pada pasal 74 ayat 1 UU Perseroan Terbatas, disebutkan bahwa perseroan yang melakukan kegiatan usaha di sektor Sumber Daya Alam harus melakukan tanggung jawab lingkungan dan sosial. (Kristianto, 2017).

Dengan adanya kewajiban pelaksanaan tanggung jawab lingkungan dan social tersebut, perseroan tentunya wajib mengeluarkan sejumlah biaya untuk menyelenggarakan CSR. Biaya tersebut nantinya dapat mempengaruhi laba bersih perusahaan, yang juga sekaligus mempengaruhi laba fiskal menurut pajak. Pelaksanaan CSR sebagai kewajiban perseroan juga dapat berdampak pada aspek perpajakan perusahaan atau perseroan tersebut.

Meskipun sudah jelas bahwa pelaksanaan CSR dapat berdampak terhadap aspek perpajakan, dalam peraturan perundang-undangan perpajakan belum disebutkan dan diatur secara langsung istilah CSR atau tanggung jawab lingkungan dan sosial (Ridho, 2017). Terkait hal tersebut, perlu dilakukan analisis dan kajian mendalam terkait konsep CSR pada aspek ketentuan perpajakan.

Menurut teori legitimasi positif, perusahaan yang sudah memiliki rating CSR yang baik akan cenderung mempertahankan legitimasi positifnya di depan para pemangku kepentingan. Legitimasi positif tersebut dipertahankan dengan cara tidak melakukan tindakan penghindaran pajak. Berdasarkan kerangka pemikiran tersebut, maka model penelitian untuk menganalisis pengaruh penyajian CSR terhadap penghindaran pajak adalah sebagai berikut.

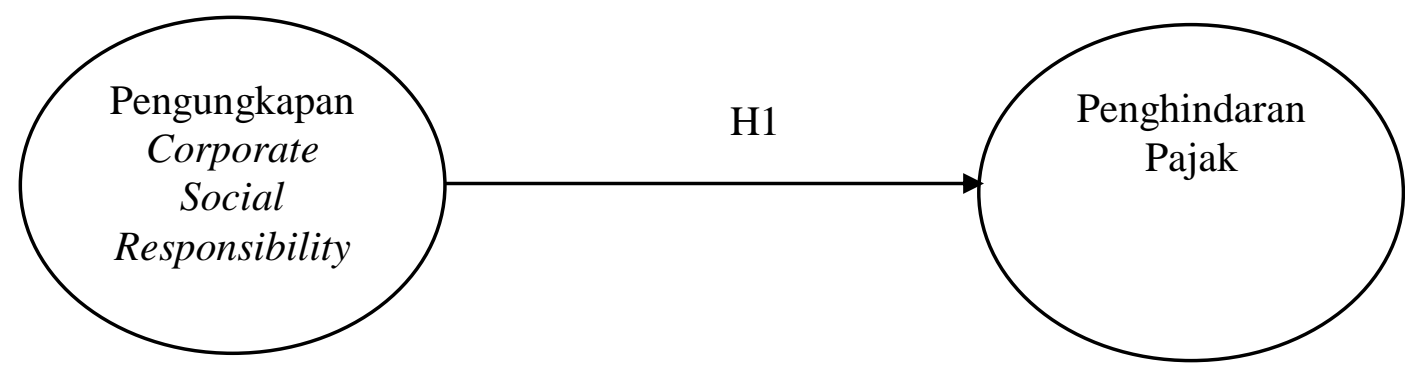

Gambar 1. Model Penelitian Uji Pengaruh Antara Pengungkapan CSR dengan Penghindaran Pajak

Sumber: Olahan Penulis 
Variabel terikat dari riset ini yaitu penghindaran pajak. Variabel terikat ini dicari dan dihitung menggunakan effective tax rate atau tariff pajak efektif suatu perusahaan. Rumus tarif pajak efektif perusahaan adalah sebagai berikut. (Titman dan Martin, 2015).

$$
\text { ETR } i, j=\frac{\text { Tax Expense } i, j}{\text { Pretax Income } i, j}
$$

$E R_{i, j}$ adalah tarif pajak efektif yang dimiliki oleh perusahaan i pada tahun $j$. Tax expense $_{i, j}$ adalah beban pajak perusahaan i pada tahun $j$, sedangkan pretax income $e_{i, j}$ adalah penghasilan atau laba bersih sebelum pajak perusahaan i pada tahun $\mathrm{j}$. Nilai ETR yang semakin tinggi mengindikasikan bahwa upaya penghindaran pajak pada perusahaan tersebut minim. Sebaliknya, nilai ETR yang semakin kecil menginterpretasikan bahwa perusahaan berpotensi untuk melaksanakan kegiatan penghindaran pajak.

Variabel independen pada riset di sini yaitu penyajian CSR yang dihitung memakai indeks penyajian CSR. Indeks atas pengungkapan CSR diformulasikan sebagai berikut.

$$
\operatorname{CSRDIj}=\frac{\sum X i j}{n}
$$

CSRDIj adalah indeks pengungkapan CSR perusahaan $\mathrm{j}$. Sigma $\mathrm{X}_{\mathrm{ij}}$ adalah jumlah atas item pengungkapan CSR menurut GRI G4 yang dijelaskan oleh perusahaan dalam sustainability report. Nilai 1 adalah nilai apabila item diungkapkan, sedangkan nilai 0 adalah nilai apabila item belum dijelaskan. $\mathrm{N}$ adalah total keseluruhan item penyajian CSR menurut GRI G4 adalah sejumlah 91 item.

Metode Analisis Data. Metode yang dipakai untuk menganalisa konsep Corporate Social Responsibility dalam aspek perpajakan yaitu analisis kualitatif. Analisis kualitatif dilaksanakan dengan mengumpulkan data yang berasal dari peraturan perundangundangan perpajakan, peraturan-peraturan mengenai pelaksanaan CSR di Indonesia, serta wawancara. Dari data-data tersebut kemudian dilakukan pemilahan data di dalam satuan konsep tertentu, kategori khusus, dan tema tertentu sehingga menghasilkan sebuah kesimpulan dari konsep mengenai CSR dalam aspek perpajakan di Indonesia

Metode analisis data untuk melihat pengaruh pengungkapan CSR terhadap penghindaran pajak adalah metode analisis kuantitatif (Nurlela, 2008; Prakosa, 2014). Proses analisis kuantitatif dimulai dari menyusun rumusan masalah berupa pengaruh pengungkapan CSR terhadap penghindaran pajak, kemudian menyusun rumusan hipotesis bahwa pengungkapan CSR berpengaruh negatif terhadap penghindaran pajak. Selanjutnya, dilaksanakan pengumpulan data berupa ETR dan CSRDIj yang didapat dari laporan keuangan tahunan serta sustainability report yang disusun oleh organisasi jasa keuangan utama yang tercatat di BEI. Data-data yang telah terkumpul tersebut dilakukan analisis data memakai analisis regresi berganda untuk melihat hasil uji pengaruh penyajian CSR terhadap penghindaran pajak. 


\section{HASIL DAN PEMBAHASAN}

Konsep CSR dalam Perpajakan. Berdasarkan UU No. 40 tahun 2007 tentang Perseroan Terbatas pada pasal 74 ayat 1 , dijelaskan bahwa perseroan yang melakukan aktivitas usahanya dalam bidang dan atau berhubungan terkait sumber daya alam harus melakukan tanggung jawab lingkungan dan sosial. Perseroan yang dimaksud dalam peraturan ini yaitu badan hukum yang merupakan persekutuan dari modal, didirikan atas dasar perjanjian, melaksanakan usaha dengan modal dasar yang sepenuhnya terbagi atas saham serta mememnuhi persyaratan yang tercantum pada UU No. 40 tahun 2007 mengenai Perseroan Terbatas dan ketentuan pelaksanaannya. Berdasarkan peraturan tersebut, pemangku kewajiban tanggung jawab lingkungan dan sosial yaitu perseroan yang melakukan usaha di bidang dan atau sumber daya alam.

UU No. 36 tahun 2008 mengenai Pajak Penghasilan, pasal 2 ayat 1 huruf $b$ dan penjelasannya menyebutkan badan, yang merupakan sekelompok orang dan atau modal yang merupakan kesatuan baik yang melaksanakan usaha atau bukan melaksanakan usaha terdiri dari perseroan terbatas, perseroan komanditer, perseroan lainnya, BUMN atau BUMD dengan nama serta bentuk apapun, dan bentuk-bentuk badan lainnya menurut pasal tersebut termasuk dalam subjek pajak. Hal tersebut berarti bahwa pemangku kewajiban tanggung jawab lingkungan dan sosial, berupa perseroan, adalah juga merupakan Subjek Pajak Badan (Bandiyono dan Husna, 2019b)

Kewajiban subjektif dari Subjek Pajak Badan dimulai sejak didirikan dan berkedudukan di Indonesia menurut pasal 2A ayat (2) UU PPh. Kewajiban tersebut berupa mendaftarkan diri sebagai wajib pajak agar mendapatkan NPWP, yang dapat dilakukan menggunakan aplikasi e-registration. Aplikasi tersebut adalah aplikasi yang dirancang oleh Kantor Pajak untuk memberi kemudahan bagi masyarakat dalam melaksanakan pendaftaran di bidang perpajakan (Bandiyono dan Chaerul, 2019). Selain itu, Subjek Pajak Badan yang telah menjadi WP Badan wajib menyelenggarakan pembukuan yang tercantum dalam pasal 28 ayat (1) UU No. 16 tahun 2009 mengenai Ketentuan Umum Perpajakan. Pembukuan wajib dilakukan dengan melihat itikad baik serta memperlihatkan kondisi riil karena hasil dari pembukuan tersebut akan menjadi dasar untuk menghitung pajak terutang dalam surat pemberitahuan (SPT). SPT adalah sarana untuk wajib pajak dalam menghitung dan menyampaikan jumlah pajak yang terutang tersebut berdasarkan penghitungan laba kena pajak perusahaan. Direktorat Jenderal Pajak telah mengembangkan aplikasi E-SPT dan E-FILLING guna memberi kemudahan untuk wajib pajak dalam menyampaikan SPT. E-SPT dan E-FILLING adalah sistem pelaporan pajak yang dilakukan secara online menggunakan media internet. (Andriani et al., 2020). Berdasarkan uraian tersebut, perseroan sebagai pemangku kewajiban Corporate Social Responsibility juga memiliki kewajiban sebagai Subjek Pajak Badan yang harus mendaftarkan diri sebagai WP, menyelenggarakan pembukuan dengan mencatat seluruh biaya yang dikeluarkan untuk menyelenggarakan CSR dengan itikad baik dan benar, serta melaporkan biaya-biaya yang terkait dengan penyelenggaraan CSR.

Meski sudah jelas bahwa perseroan sebagai pemangku kewajiban CSR juga merupakan Wajib Pajak, UU PPh belum menyatakan secara langsung aturan yang mengatur biaya yang dikeluarkan untuk melakukan kewajiban tanggung jawab lingkungan dan sosial. Hal ini dapat menimbulkan bias bagi para pengguna peraturan jika mereka 
tidak menggali lebih dalam, karena dalam UU PPh belum disebutkan secara langsung istilah tanggung jawab lingkungan dan sosial beserta peraturan perpajakan yang terkait.

Meskipun UU Pajak Penghasilan belum mengatur secara langsung istilah tanggung jawab lingkungan dan sosial beserta biaya atas penerapan CSR tersebut, terdapat beberapa biaya dalam UU PPh yang selaras dengan indikator pengungkapan Corporate Social Responsibility menurut standar pelaporan berkelanjutan GRI G4. Rincian jenis biaya tanggung jawab lingkungan dan sosial yang diatur pada UU PPh berdasarkan riset kepustakaan oleh penulis adalah sebagai berikut: (1) Biaya terkait pekerjaan atau jasa termasuk gaji, honorarium, upah, gratifikasi, bonus, dan tunjangan yang diserahkan dalam bentuk uang. (2) Premi asuransi kepada karyawan. (3) Biaya pengolahan limbah. (4) Biaya pelatihan dan beasiswa. (5) Pembentukan atau Pemupukan Dana Cadangan Biaya Reklamasi, Biaya Penanaman Kembali, dan biaya pemeliharaan serta penutupan tempat pembuangan limbah industry.

Selain kelima jenis biaya di atas, terdapat biaya tanggung jawab lingkungan dan sosial yang juga bisa dikurangi dari penghasilan kotor, yaitu biaya sumbangan. Biaya sumbangan merupakan biaya yang bisa dikurangi dari pendapatan kotor Wajib Pajak. Jenis-jenis biaya sumbangan tersebut disebutkan dalam pasal 6 UU Pajak Penghasilan. Berdasarkan wawancara dengan dua Account Representative KPP Madya Semarang, Bapak Irfan dan Bapak Chasa, beberapa biaya sumbangan dimaksud termasuk dalam biaya yang dikeluarkan untuk Corporate Social Responsibility. Berdasarkan pengalaman mereka, dalam laporan keuangannya, Wajib Pajak biasanya mencantumkan biaya tersebut dalam akun biaya sumbangan. Namun, terdapat kriteria dan batasan tertentu yang wajib dipenuhi agar biaya sumbangan tersebut bisa dikurangi dari pendapatan kotor. Kriteria dan batas yang dimaksud diatur khusus di PP No. 93 tahun 2010. Jenis-jenis sumbangan tersebut adalah sumbangan untuk penanggulangan bencana nasional, sumbangan untuk pengembangan dan riset di Indonesia, biaya pembangunan infrastruktur social, sumbangan pendidikan, dan sumbangan pembinaan olahraga.

Berdasarkan uraian pembahasan di atas, keberadaan kewajiban penyelenggaraan tanggung jawab lingkungan dan sosial perusahaan yang ada di Undang-Undang PT ternyata berimbas pula pada pemenuhan kewajiban perpajakan perusahaan atau perseroan. Namun, jika ditinjau dari segi peraturan, istilah tanggung jawab lingkungan dan sosial hanya disebutkan pada UU No. 40 tahun 2007 mengenai Perseroan Terbatas saja. Sedangkan pada peraturan perundang-undangan perpajakan, belum diatur secara langsung istilah tanggung jawab lingkungan dan sosial perusahaan.

Peraturan perpajakan khususnya UU PPh belum mengatur secara langsung dan khusus terkait tanggung jawab lingkungan dan sosial. UU PPh hanya mengatur beberapa biaya yang dapat dan tidak boleh dikurangi dari pendapatan kotor dalam pasal 6 dan pasal 9 berdasarkan jenis biayanya. Biaya-biaya tersebut belum digolongkan secara langsung mana yang termasuk biaya tanggung jawab lingkungan dan sosial.

Konsep mengenai biaya tanggung jawab lingkungan dan sosial baru bisa diketahui apabila dilakukan analisis lebih lanjut terhadap pasal 6 dan pasal 9. Jika dianalisis lebih lanjut, ternyata terdapat biaya-biaya, baik yang bisa dikurangi atau tidak bisa dikurangi dari pendapatan kotor, yang selaras dengan indikator-indikator pelaksanaan dan penyajian CSR menurut standar internasional penyajian CSR GRI G4 dalam sustainability report. Namun, kedua pasal tersebut hanya memuat beberapa indikator saja, belum mencakup seluruh indicator yang ada di GRI G4. 
Analisis Deskriptif Pengungkapan CSR pada Sustainability Report yang Disusun Oleh Perusahaan Jasa Keuangan Utama yang Terdaftar di BEI. Populasi dalam riset ini yaitu perusahaan jasa keuangan utama yang tercatat pada BEI di periode 2015 s.d. 2016. Pada riset ini, data yang dipakai yaitu data sekunder berbentuk laporan keuangan tahunan perusahaan yang dipublish pada laman BEI dan perusahaan. Selain itu, juga dibutuhkan data sekunder berupa sustainability report yang sudah diverifikasi oleh Global Reporting Initiatives memenuhi standar GRI G4. Laporan keberlanjutan tersebut dapat diunduh pada website Global Reporting Initiatives. Dalam penelitian ini, digunakan metode sampling bersasaran (purposive sampling) dengan maksud supaya didapatkan sampel yang representative sesuai kriteria yang dimaksud.

Pemilihan sampel pada riset ini yaitu: perusahaan jasa keuangan utama yang terdaftar di BEI pada tahun 2015 s.d. 2016 dan mempublikasi laporan keuangan tahunannya adalah sebanyak 48 perusahaan, sehingga didapat jumlah sebesar 96. Data laporan keberlanjutan yang telah diverifikasi oleh GRI sesuai dengan standar GRI G4 dan dapat diunduh di website database GRI sebanyak 20 sampel. Jadi, didapat jumlah sampel untuk diproses sebesar 20 sampel.

Di bawah ini hasil analisis statistik deskriptif dari variabel dependen berupa effective tax rate (ETR) serta variabel independent berupa CSR Disclosure Index (CSRDI).

Tabel 1. Analisis Deskriptif Pengungkapan CSR dan ETR

\begin{tabular}{l|r|r|r|r|r}
\hline & N & Minimum & Maximum & Mean & Std. Deviation \\
\hline CSRDI & 20 & 10.00 & 63.00 & 27.2000 & 13.75576 \\
ETR & 20 & -25.00 & 30.00 & 20.6500 & 11.25903 \\
Valid N & 20 & & & & \\
(listwise) & & & & \\
Sumber: Olahan Penulis
\end{tabular}

Berdasarkan tabel analisis deskriptif, pengujian atas 20 sampel amatan menunjukkan bahwa variabel tarif pajak efektif (ETR) memiliki rata-rata sebesar 20,65\% atau 0,2065. Nilai minimum dari tarif pajak efektif diperoleh Bank Permata Tbk. pada tahun 2016 yaitu sebesar -25,00. Nilai minus dari tarif pajak efektif tersebut dikarenakan Bank Permata Tbk. mengalami rugi sebelum pajak pada tahun 2016. Nilai maksimum dari ETR diperoleh Bank Pembangunan Daerah Jawa Timur Tbk. sebesar 30\% atau 0,3. Standar deviasi dari ETR adalah $11,26 \%$ atau 0,1126

Pengujian atas 20 sampel amatan menunjukkan bahwa variabel indeks pengungkapan CSR (CSRDI) memiliki rata-rata sebesar 27,2\% atau 0,272. Rata-rata tersebut dapat dikatakan cukup kecil, yang berarti rata-rata perusahaan jasa keuangan utama yang terdaftar di BEI hanya mengungkapkan 25 (dua puluh lima) dari 91 (sembilan puluh satu) item atau indikator pengungkapan CSR menurut GRI G4. Nilai minimum dari CSRDI adalah sebesar 10\% atau 0,1 yang diperoleh Bank Rakyat Indonesia (Persero) Tbk. Sedangkan indeks pengungkapan CSR (CSRDI) tertinggi.

Pengaruh Pengungkapan CSR terhadap Tindakan Penghindaran Pajak pada Perusahaan Jasa Keuangan yang terdaftar di BEI. Model yang dipakai dalam mencari 
pengaruh variable bebas yaitu CSR terhadap variable terikat yaitu praktek penghindaran pajak yang diwakili oleh ETR yaitu model regresi linier beranda. Di bawah ini merupakan tabel hasil uji analisis regresi linier berganda.

Table 2. Hasil Analisis Regresi Linier Berganda

\begin{tabular}{|c|c|c|c|c|c|c|}
\hline \multirow{2}{*}{\multicolumn{2}{|c|}{ Model }} & \multicolumn{2}{|c|}{ Unstandardized Coefficients } & $\begin{array}{l}\text { Standardized } \\
\text { Coefficients }\end{array}$ & \multirow[b]{2}{*}{$\mathrm{T}$} & \multirow[b]{2}{*}{ Sig. } \\
\hline & & $\mathrm{B}$ & Std. Error & Beta & & \\
\hline \multirow[t]{2}{*}{1} & (Constant) & 20.170 & 5.849 & & 3.449 & .003 \\
\hline & CSRDI & .018 & .193 & .022 & .091 & .928 \\
\hline
\end{tabular}

a. Dependent Variable: ETR

Sumber: Olahan penulis

Menurut tabel di atas, bisa diketahui persamaan regresi pada penelitian ini dirumuskan sebagai berikut.

$$
E T R=0,018 \operatorname{CSRDI}+20,170+e
$$

Penjelasan atas persamaan di atas yaitu: (1) Nilai konstanta sebesar 20,170 artinya bahwa apabila nilai variabel bebas yaitu pengungkapan CSR bernilai nol, maka effective tax rate akan bernilai 20,17\% atau 0,2017. (2) Nilai beta atau koefisien variabel dependen CSR adalah 0,018. Hal tersebut berarti apabila nilai CSRDI mendapatkan peningkatan senilai 1 satuan, sehingga nilai ETR akan mendapatkan kenaikan juga sejumlah 0,018 atau 1,8\%.

$\mathrm{H}_{0}$ : Sig. > 0.05 : artinya bahwa CSR tidak memiliki pengaruh signifikan positif terhadap ETR

$\mathrm{H}_{1}$ : Sig. $\leq 0,05$ : artinya bahwa CSR memiliki pengaruh signifikan positif atas ETR

Berdasarkan uji statistic t, variabel bebas yang mengungkapkan CSR menghasilkan nilai signifikansi sejumlah 0,928 . Angka tersebut lebih besar dari nilai signifikansi yang dipakai adalah sejumlah 0,05 . Hal tersebut berarti hipotesis 0 diterima, dan penyajian CSR pada sustainability report tidak mempunyai pengaruh positif signifikan atas ETR. Sehingga, hipotesis yang menyatakan pengungkapan CSR pada sustainability report mempunyai pengaruh positif signifikan atas ETR ditolak. Hasil riset ini mendukung riset yang dikerjakan oleh (Hidayah, 2017); (Putranti dan Tambunan, 2015) yang mengungkapkan bahwa CSR tidak memiliki pengaruh signifikan atas praktek penghindaran pajak. Riset ini beda dengan riset yang dikerjakan oleh (Muzakki dan Darsono, 2015) yang menyatakan bahwa CSR memiliki pengaruh positif atas ETR yang mengindikasikan minimnya penghindaran pajak, atau dalam arti langsung CSR memiliki pengaruh negative atas penghindaran pajak.

Hasil yang menunjukkan bahwa penyajian CSR tidak memiliki pengaruh signifikan atas tindakan penghindaran pajak bisa dijadikan acuan bahwa dalam mencari indikasi tindakan penghindaran pajak, Direktorat Jenderal Pajak dapat mempertimbangkan 
indikator-indikator penghindaran pajak selain Corporate Social Responsibility. Dalam arti lain, indikator pengungkapan Corporate Social Responsibility dapat dikatakan kurang akurat dalam mengindikasikan penghindaran pajak. Berdasarkan wawancara yang penulis lakukan dengan Account Representative Kantor Pelayanan Pajak Madya Semarang, Bapak Chasa dan Bapak Irfan, Wajib Pajak biasanya tidak menggunakan akun biaya sumbangan sebagai sarana untuk melakukan praktik penghindaran pajak. Mereka menyatakan pula, seandainya saja Wajib Pajak menggunakan biaya sumbangan sebagai sarana penghindaran pajak, jumlahnya tidak terlalu signifikan. Contoh indikator-indikator tindakan penghindaran pajak selain Corporate Social Responsibility dapat dilihat pada penelitianpenelitian sebelumnya mengenai tindakan penghindaran pajak.

Menurut (Darmawan dan Sukartha, 2014), faktor yang berpengaruh positif signifikan terhadap penghindaran pajak adalah Return On Asset (ROA) dan ukuran perusahaan. ROA dan ukuran perusahaan dapat digunakan Direktorat Jenderal Pajak sebagai indikasi awal untuk meneliti adanya praktik penghindaran pajak. Selain ROA, profitabilitas dan pertumbuhan penjualan berpengaruh negatif terhadap penghindaran pajak. Kedua indikator tersebut telah diuji oleh (Hidayat, 2018) dalam penelitiannya. Profitabilitas dan pertumbuhan penjualan dapat juga dijadikan indikator untuk mengetahui tindakan penghindaran pajak. Berdasarkan (Abdullah, 2020), tingkat likuiditas dan leverage perusahaan berpengaruh signifikan terhadap penghindaran pajak. Terkait hal tersebut, tingkat likuiditas dan leverage dari perusahaan dapat digunakan oleh DJP sebagai indikator untuk mendeteksi adanya tindakan penghindaran pajak.

\section{KESIMPULAN}

Peraturan dan hukum di Indonesia telah mengatur secara langsung kewajiban mengenai pertanggungjawaban oleh Perusahaan. Hal tersebut tertuang dalam UU Perseroan Terbatas. Kewajiban penyelenggaraan Corporate Social Responsibility membutuhkan biaya yang akan mempengaruhi laba bersih perusahaan. Secara otomatis, terpengaruhnya laba bersih perusahaan juga akan menyebabkan laba fiskal dalam aspek perpajakan terpengaruh. Namun, dalam peraturan perpajakan, khususnya UU No. 36 Tahun 2008 tentang Pajak Penghasilan belum mengatur dan menyebutkan secara langsung istilah tanggung jawab lingkungan dan sosial perusahaan. Hal ini bisa menyebabkan bias bagi para pemangku kewajiban tanggung jawab lingkungan dan sosial, yaitu perusahaan, organisasi, serta entitas bisnis. Namun, jika dianalisis lebih lanjut, UU No. 36 tahun 2008 tentang Pajak Penghasilan secara tidak langsung berisi sebagian konsep mengenai Corporate Social Responsibility yang sesuai dengan standar pengungkapan pelaksanaan CSR internasional dalam pelaporan berkelanjutan, yaitu Global Reporting Initiatives (GRI) G4 standart. Pada pasal 6 dan 9 UU PPh, ditemukan beberapa biaya yang sejalan dengan indikator pengungkapan CSR pada GRI G4 standart.

Berdasarkan hasil analisis deskriptif indeks pengungkapan CSR dalam pelaporan keberlanjutan, rata-rata indeks pengungkapan CSR yaitu sebesar 27,2\%. Angka tersebut dapat dikatakan relatif kecil, yang berarti perusahaan jasa keuangan utama yang terdaftar di BEI rata-rata hanya mengungkapkan 25 (dua puluh lima) item atau indikator pengungkapan CSR dari 91 (sembilan puluh satu) item pengungkapan CSR menurut GRI G4. 
Berdasarkan uji pengaruh antara pengungkapan CSR terhadap penghindaran pajak yang diindikasikan melalui effective tax rate (ETR), variabel pengungkapan Corporate Social Responsibility memiliki nilai signifikansi sejumlah 0,928 . Nilai tersebut lebih besar dari nilai signifikansi yang digunakan dalam penelitian yaitu $0,928>0,05$. Hal tersebut berarti pengungkapan Corporate Social Responsibility tidak berpengaruh positif signifikan terhadap ETR yang menunjukkan juga bahwa CSR tidak berpengaruh negatif signifikan terhadap praktik penghindaran pajak. Berdasarkan wawancara penulis terhadap Account Representative KPP Madya Semarang, Bapak Irfan dan Bapak Chassa, mereka juga menyatakan bahwa Wajib Pajak biasanya tidak menggunakan akun biaya sumbangan sebagai sarana untuk melakukan praktik penghindaran pajak. Mereka menyatakan pula, seandainya saja Wajib Pajak menggunakan biaya sumbangan sebagai sarana penghindaran pajak, jumlahnya tidak terlalu signifikan. Oleh karena itu, apabila hendak meneliti indikasi praktik penghindaran pajak, dapat digunakan indikator-indikator lain selain pengungkapan Corporate Social Responsibility. Indikator lain tersebut dapat berupa Return On Asset, profitabilitas, dan pertumbuhan penjualan perusahaan.

\section{DAFTAR PUSTAKA}

Abdullah, I. (2020). Pengaruh Likuiditas dan Leverage Terhadap Penghindaran Pajak Pada Perusahaan Makanan dan Minuman. Jurnal Riset Akuntansi dan Bisnis 20.1, 16-22.

Andriani, R. N., Hermansyah, I., dan Fadilah, A. R. (2020). Pengaruh Fasilitas E-Spt Dan E-Filing Dalam Penyampaian Surat Pemberitahuan (SPT) Terhadap Kepatuhan Wajib Pajak Badan (Survei Wajib Pajak Badan yang terdaftar di KPP Pratama Kota Tasikmalaya). JURNAL AKUNTANSI, 15(1), 28-35.

Angrayani, N. (2016). Pengaruh Pengungkapan Corporate Social Responsibility dan Kepemilikan Manajerial Terhadap Nilai Perusahaan dengan Profitabilitas Sebagai Variabel Moderating (Studi Empiris Pada Perusahaan Manufaktur di Indonesia dan Singapura Periode 2014.

Awaliyah, M., dan Vestari, M. (2018). Analisis Pengungkapan Corporate Social Responsibility Perbankan Syariah di Indonesia. Magisma: Jurnal Ilmiah Ekonomi dan Bisnis 6.2 , 52-66.

Azra, T. (2012). Suatu Kajian Literatur: Implementasi Corporate Social Reponsibility di Indonesia. Polibisnis Vol 4(1).

Bandiyono, A., and Husna, M. C. (2019b). Services E-Filling and E-Billing To Increase Tax Compliance and Acceptance. Dinasti International Journal of Education Management And Social Science 1.2, 208-223.

Bandiyono, A., dan Chaerul, I. F. (2019a). Layanan Penyelesaian Permohonan Pendaftaran NPWP Melalui Aplikasi Registrasi Elektronik. Jurnal Demokrasi Dan Otonomi Daerah 17.2, 137-144.

Bursa Efek Indonesia. (2020, Juni 23). Sejarah dan Milestone. Retrieved from Website Bursa Efek Indonesia: https://www.idx.co.id/tentang-bei/sejarah-dan-milestone/

Darmawan, I. G., dan Sukartha, I. M. (2014). Pengaruh Penerapan Corporate Governance, Leverage, Return On Assets, dan Ukuran Perusahaan Pada Penghindaran Pajak. EJurnal Akuntansi Universitas Udayana Vol. 9.1, 143-161. 
Dewi, N. L., dan Noviari, N. (2017). Pengaruh Ukuran Perusahaan, Leverage, Profitabilitas, dan Corporate Social Responsibility Terhadap Penghindaran Pajak (Tax Avoidance). E-Jurnal Akuntansi Universitas Udayana Vol.21.1, 830-859.

Femitasari, L. (2014). Pengaruh Proporsi Dewan Komisaris Independen, Kepemilikan Institusional dan Corporate Social Responsibility Terhadap Agresivitas Pajak. Disertasi Widya Mandala Catholic University.

Global Reporting Initiative. (2020, Juni 10). GRI's History. Retrieved from Global Reporting Initiative Website: https://www.globalreporting.org/information/aboutgri/gri-history/Pages/GRI\%27s\%20history.aspx

Global Reporting Initiatives. (2016). G4: Pedoman Pelaporan Berkelanjutan, PrinsipPrinsip Pelaporan dan Pengungkapan Standar. Amsterdam: Global Reporting Initiatives.

Global Reporting Initiatives. (2020, Juni 10). About Us: Global Reporting Initiatives. Retrieved from Global Reporting Initiatives Website: https://www.globalreporting.org/information/about-gri/Pages/default.aspx

Harahap, A. S. (2010). Pengaturan Corporate Social Responsibility (CSR) di Indonesia. Lex Jurnalica 7.3.

Hidayah, A. L. (2017). Pengaruh Corporate Social Responsibility, Profitabilitas, Leverage Dan Komisaris Independen Terhadap Praktik Penghindaran Pajak. Disertasi Universitas Muhammadiyah Purwokerto.

Hidayat, W. W. (2018). Pengaruh Profitabilitas, Leverage Dan Pertumbuhan Penjualan Terhadap Penghindaran Pajak. Jurnal Riset Manajemen dan Bisnis (JRMB) Fakultas Ekonomi UNIAT 3.1, 19-26.

Hopkins, M. (2003). The Planetary Bargain: Corporate Social Responsibility Matters. London: Earthscan Publication Ltd.

Hutagaol, J., Winarno, W. W., dan Pradipta, A. (2007). Strategi meningkatkan kepatuhan wajib pajak. Jurnal akuntabilitas, 6(2), 186-193.

Indrawan, D. C., dan Siti Mutmainah, S. M. (2011). Pengaruh Corporate Social Responsibility Terhadap Kinerja Perusahaan (Doctoral dissertation, Universitas Diponegoro).

Khafid, M., dan Mulyaningsih. (2018). Kontribusi Karakteristik Perusahaan Dan Corporate Governance Terhadap Publikasi Sustainability Report. EKUITAS (Jurnal Ekonomi dan Keuangan) 19.3, 340-359.

Kolk, A. (1989). A Decade of Sustainability Reporting: Developments and Significance. International Journal of Environment and Sustainable Development, 51-64.

Kristianto, C. (2017). Pengaruh audit tenure, profitabilitas, umur perusahaan, dan ukuran perusahaan terhadap kecepatan publikasi laporan keuangan. Desertasi Widya Mandala Catholic University.

Lanis, R., and Richardson, G. (2012). Corporate social responsibility and tax aggressiveness: a test of legitimacy theory. Accounting, Auditing, and Accountability Journal, 75-100.

Mahendra, R. (2015). ISOCENTER INDONESIA. Retrieved Juli 9, 2020, from ISO 26000 sebagai Standar Global dalam Pelaksanaan CSR: https://isoindonesiacenter.com/sekilas-tentang-iso-26000/

Mualiffin, O. R. (2016). Dampak Pengungkapan Sustainability Report Terhadap Kinerja Keuangan dan Kinerja Pasar. Jurnal Ilmu dan Riset Akuntansi, Vol. 5, No. 11, 1-20. 
Muzakki, M. R., dan Darsono. (2015). Pengaruh Corporate Social Responsibility Dan Capital Intensity Terhadap Penghindaran Pajak. Diponegoro Journal of Accounting 4.3, 445-452.

Noor, J. (2011). Metodologi Penelitian: Skripsi, Tesis, Disertasi, dan Karya Ilmiah. Jakarta: Prenadamedia.

Nurlela, I. (2008). Pengaruh Corporate Social Responsibility Terhadap Nilai Perusahaan Dengan Prosentase Kepemilikan Manajemen Sebagai Variabel Moderating. Simposium Nasional Akuntansi XI.

Pemerintah Republik Indonesia. 2010. Peraturan Pemerintah Republik Indonesia Nomor 93 Tahun 2010 tentang Sumbangan Penanggulangan Bencana Nasional, Sumbangan Penelitian Dan Pengembangan, Sumbangan Fasilitas Pendidikan, Sumbangan Pembinaan Olahraga, Dan Biaya Pembangunan Infrastruktur Sosial Yang Dapat Dikurangkan Dari Penghasilan Bruto. Jakarta: Pemerintah Republik Indonesia.

Prakosa, K. B. (2014). Prakosa, Kesit Bambang. "Pengaruh profitabilitas, kepemilikan keluarga dan corporate governance terhadap penghindaran pajak di Indonesia. Simposium Nasional Akuntansi 17.2, 24-27.

Putranti, T. M., Jati, W., dan Tambunan, M. R. (2015). Studi Penghindaran Pajak Kegiatan Jasa Perbankan di Indonesia. Responsi Bank Indonesia.

Republik Indonesia. 2007. Undang-undang Republik Indonesia Nomor 28 Tahun 2007 tentang Perubahan Ketiga Atas Undang-undang Nomor 6 Tahun 1983 Tentang Ketentuan Umum dan Tata Cara Perpajakan. Jakarta: Sekretariat Negara.

Republik Indonesia. 2007. Undang-undang Republik Indonesia Nomor 40 Tahun 2007 tentang Perseroan Terbatas. Jakarta: Sekretariat Negara.

Republik Indonesia. 2008. Undang-undang Republik Indonesia Nomor 32 Tahun 2008 tentang Perubahan Keempat Atas Undang-undang Nomor 7 Tahun 1983 Tentang Pajak Penghasilan. Jakarta: Sekretariat Negara.

Ridho, T. K. (2017). CSR In Indonesia: Company's Perception and Implementasion. The EUrASEANs: journal on global socio-economic dynamics Vol 3(4).

Sayekti, Y., dan Wondabio, L. S. (2007). Pengaruh CSR Disclosure Terhadap Earning Response Coefficient (Studi Empiris Pada Perusahaan Yang Terdaftar DI Bursa Efek Jakarta). SImposium Nasional Akuntansi $X$ (pp. 1-35). Makassar: Unhas Makassar.

Sudaryo, Y., dan Yudanegara, A. (2017). Investasi Bank dan Lembaga Keuangan. Yogyakarta: Andi.

Sugiyono. (2013). Metode Penelitian Pendidikan Pendekatan Kuantitatif, Kualitatif, dan $R \& D$. Bandung: Alfabeta.

Titman, S., Keown, A. J., and Martin, J. D. (2015). FInancial Management: Principles and Applications. Frenchs Forest: Pearson.

United Nations Industrial Development Organization. (2020, Juni 4). What Is CSR? Retrieved from UNIDO Website: https://www.unido.org/our-focus/advancingeconomic-competitiveness/competitive-trade-capacities-and-corporateresponsibility/corporate-social-responsibility-market-integration/what-csr

Weber, J., and Wasieleski, D. M. (2018). Corporate Social Responsibility: Business \& Society 360. Bingley: Emerald Publishing Ltd. 
Whait, R. B., Christ, K. L., Ortas, E., and Burrit, R. L. (2018). What do we know about tax aggresiveness and corporate social responsibility? An integrate review. Journal of Cleaner Production, 542-552.

Wibowo, I., dan Faradiza, S. A. (2014). Dampak Pengungkapan Sustainability Report Terhadap Kinerja Keuangan dan Pasar Perusahaan. SImposium Nasional Akuntansi XVII. Lombok: Jurusan Akuntansi Fakultas Ekonomi Universitas Lombok.

Widianto, H. S. (2011). Pengaruh Profitabilitas, Likuiditas, Leverage, Aktivitas, Ukuran Perusahaan, dan Corporate Governance Terhadap Praktik Pengungkapan Sustainability Report. Skrips Fakultas Ekonomi Universitas Diponegoro Semarang.

Wulolo, C. F., and Rahmawati, I. P. (2017). Analisis Pengungkapan Corporate Social Responsibility Berdasarkan Global Reporting Initiative. Jurnal Organisasi dan Manajemen.

Yoehana, M. (2013). Analisis Pengaruh Corporate Social Responsibility Terhadap Agresivitas Pajak (Studi Empiris pada Perusahaan Manufaktur yang Terdaftar di Bursa Efek Indonesia Tahun 2010-2011). Disertasi Fakultas Ekonomika dan Bisnis. 